\section{Work Safety During Usage, Repair and Maintenance of Machines - a Review of Work Safety in the Aspect of Accidents at Work}

\author{
Tomasz Małysa \\ Silesian University of Technology, Poland
}

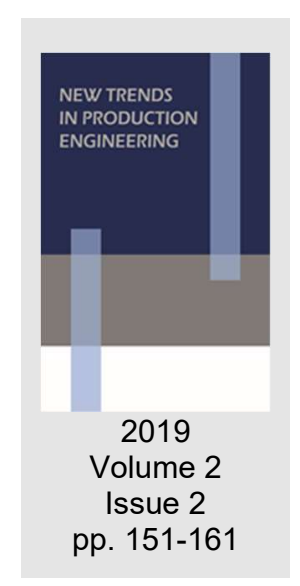

Date of submission to the Editor: 09/2019

Date of acceptance by the Editor: $11 / 2019$

\title{
INTRODUCTION
}

The occurrence of accidents at work is currently a problem for many industrial enterprises, due to the social and economic costs of occurring events. Therefore, employers should take all actions aimed at improving safety at a workplace. The subject of the paper is the analysis of accident events that take place during the use, repair and maintenance of machines in Poland. In accordance with the applicable legal regulations, the machinery park used should meet the minimum or basic requirements. Employers, as work organizers, were obliged to ensure that the machines used by employees meet safety requirements throughout their lifetime.

The aim of the conducted analysis is to present the dependence between the number of accidents, taking into account their severity, and demographic characteristics (gender, age of the victim). The implementation of the assumed objective was possible due to the development of the adopted methodology of the conducted research and analysis. The adopted methodology included in its scope the absolute analysis of accidents in the use, repair and maintenance of machines, the accident indicator analysis and the determination of activities during which the analysed accident events occur.

The study also includes proposing preventive solutions that can be implemented in production enterprises. Implementation of the proposed prophylaxis can effectively translate into improvement of occupational health and safety, and above all the limitation of the number of accidents when using, repairing and maintaining machines. Therefore, the following thesis can be stated that effective prophylaxis, adjusted to the identified threats, may translate into an improvement in the safety of the organization. The undertaken activities will also be perceived by the employees as a manifestation of management's involvement in activities aimed at improving safety and ergonomics in the work environment. 


\section{PROBLEMATICS OF ACCIDENTS AT WORK}

By the concept of an accident is meant a sudden event, unpredictable, as a result of which people are injured, lose their lives, suffer losses. Places and activities give the basis for their classification into: professional - related to the work performed and non-work activities that are not related to professional work, which include, among others, transport, aviation, construction and other accidents. In Polish legislation, the term occupational accident is understood as an emergency event caused by an external cause, causing injury or death of an employee and related to the work performed (Act of October 30, 2002, Lis \& Nowacki, 2005). All four accident characteristics specified in the definition must occur simultaneously (Małysa et al., 2017). In the study, selected areas were analysed, which may become the causes of accidents at work during the use, repair and maintenance of machines. These areas include:

- failure to meet minimum or essential requirements by machines operated in enterprises;

- absence of usage of available solutions affecting the improvement of safety - proper organization of work, ensuring order at the workplace, marking hazardous areas, securing the machine during repairs and maintenance, training.

The basic element in the field of occupational safety in the use, repair and maintenance of machines is the fulfilment of legal requirements by the operated machines as well as compliance with the regulations and rules of health and safety at work for the employees of the enterprise. The legislator in legal regulations has diversified the safety requirements for machines. The EU concept assumes two pillars regarding the minimum and essential requirements. The entity responsible for ensuring safety in the place of machine use is the employer (minimum requirements) while in the case of machines placed on the European market (essential requirements) - the producer is responsible.

Minimum requirements regarding the so-called old machines - used in industrial enterprises before Poland joined the structures of the European Union. These requirements are set out in Directive 2009/104/EC of the European Parliament and of the Council concerning minimum safety and hygiene requirements for the use of work equipment by employees at work (Directive, 2009). The provisions of the directive in accordance with applicable Community law should be effectively implemented into national law. In connection with the above, the provisions of the tooling directive were transposed by the ordinance of the Minister of Economy on the minimum requirements regarding occupational health and safety in the field of the use of machines by employees at work (Regulation of the Minister of Economy, 2002). In legal acts (Directive, 2009; Regulation of the Minister of Economy, 2002) the legislator specified the obligations of employers with regard to minimum safety requirements for broadly understood work equipment, including machines.

In accordance with the applicable legal regulations, the employer should take steps to ensure that the machines made available at the workplace or in the 
place designated by the employer are appropriate to perform the work or appropriately adapted to its performance. Carrying out these activities, the employer should also apply solutions that minimize the risks associated with their exploitation. Minimum requirements regarding technical aspects related to work safety are set out in Chapter 3 of the Regulation of the Minister of Economy (Regulation of the Minister of Economy, 2002).

The basic requirements concern the so-called new machines - placed on the market/put into service after the country's accession to EU structures. They are directed to producers, importers and distributors (Małysa \& Pawlak, 2017; Małysa et al., 2016) and are set out in Directive 2006/42/EC of the European Parliament and of the Council on machinery (Directive, 2006). The provisions of the Machinery Directive have been implemented into national legislation by the Regulation of the Minister of Economy on the essential requirements for machinery. The essential requirements set by the legislator are to guarantee the user a higher level of security than the minimum requirements. In connection with the above, the introducing machines on the market entity must identify the essential requirements that apply to its product and take actions ensuring the user a high level of safety. The essential requirements, dedicated to manufacturers, concern a wider group of technical aspects in which the manufacturer must ensure safety, at a level higher than was discussed in the scope of minimum requirements. The producer has also been obliged to provide documentation regarding safe use (installation, use, repair and maintenance of the machine).

Employers when organizing working conditions have to bear in mind that accidents at work in enterprises that have machines in their equipment most often occur during their use, repair or maintenance. Therefore, from the Labour Code (Labour Code, 1974) results the employer's obligation to ensure safe and hygienic working conditions. In particular, the employer is to ensure that the machines and other technical devices used provide safe and hygienic working conditions, in particular to protect the employee from injuries, hazardous chemicals, electric shock, excessive noise, mechanical vibrations, harmful and dangerous effects of other working environment factors.

Meeting legal requirements allows to ensure work safety, however, the occurrence of accidents in the use, repair and maintenance of machines may result from organizational reasons, therefore good practices that may contribute to reducing the number of accident events should be implemented. Such solutions can include implementation of (Gala, 2013; Furman et al., 2018; Moeuf et al., 2016; Furman et al., 2017; Kuczyńska-Chałada et al., 2017; Gajdzik et al., 2017; Lis et al., 2016, Gajdzik, 2013; Wolniak, 2013):

- Lockout Tagout system - a system of locks and hangers that allows you to protect the machine against accidental activation during repair or maintenance by unauthorized persons;

- selected Lean Manufacturing tools - 5S - aimed at ensuring order and proper organization of work at the workplace, Visual Management - visualization of dangerous zones, information on hazard areas. 
An important element is the implementation of available solutions to improve occupational safety while using, repairing and maintaining machines. Therefore, employers should implement solutions that have a significant impact on reducing the number of accidents at work.

\section{METHODOLOGY OF RESERARCH AND ANALYSIS}

The analysis of accidents in the use, repair and maintenance of machines was carried out based on the data of the Central Statistical Office (Stat. Gov, 201317). It included a summary of data on accidents at work in 2013-2017. Having in mind the assumed goal of the study, the research and analysis were divided into three stages, in which the following were carried out:

- absolute analysis of accidents at work in the use, repair and maintenance of machines - the following were summarized: the data on the number of total accidents, the number of people injured in accidents at work with division into serious, fatal, collective and other accidents as well as the number of days of incapacity to work;

- ratio accident analysis, which included determining the severity and accident rates at work in the use, repair and maintenance of machines;

- identification of activities during which accidents occur when using, repairing and maintaining machines.

\section{ABSOLUTE ANALYSIS OF ACCIDENTS AT WORK}

Absolute analysis of accidents in the use, repair and maintenance of machines was based on the comparison and analysis of the number of accidents, the number of people injured in accidents, the number of days of incapacity to work caused by these events in 2013-2017. In order to analyse the variation of accident rates in the use, repair and maintenance of machines, characteristics of descriptive statistics were determined, such as: arithmetic mean, median, minimum and maximum value and standard deviation for each of the analysed data. The coefficient of variation was also determined, which is expressed as a percentage share of the standard deviation divided by the arithmetic mean value. For the purpose of this study, the following interpretation of the coefficient of variation was adopted: up to $25 \%$ small volatility, above $25 \%$ to $45 \%-$ moderate volatility, over $45 \%$ to $65 \%$ - large volatility, over $65 \%$ to $100 \%$ very large volatility. Accident statistics of events - accidents in total, injured in accidents in total and selected characteristics of descriptive statistics, allowing the analysis of accidents are presented in Table 1.

Table 1 Selected characteristics of descriptive statistics of accidents at work/injured in total
\begin{tabular}{|c|c|c|c|c|c|c|}
\hline Specification & Median & Min & Max & $\begin{array}{c}\text { Deviation } \\
\text { standard }\end{array}$ & Average & $\begin{array}{c}\text { Coefficient } \\
\text { of variation, \% }\end{array}$ \\
\hline Total accidents & 1095 & 1036 & 1099 & 27.6 & 1078 & 2.6 \\
\hline $\begin{array}{c}\text { Injured in total } \\
\text { accidents }\end{array}$ & 1100 & 1048 & 1110 & 24.7 & 1088 & 2.3 \\
\hline
\end{tabular}

In the analysed period - 2013-2017, 1078 of total accidents were registered on average, while the average number of injured persons was 1088 . On the basis 
of the analysis, an upward trend in total accidents in 2013-2014, a decrease in 2015-16, followed by an increase in 2017 was observed. In the case of the number of people injured in total accidents, alternating changes were recorded indicating growth $(2014,2017)$ and declines in relation to them $(2013,2015$, 2016). A clear downward trend was recorded in 2016 in relation to the remaining time period being analysed. The determined coefficient of variation for total accidents was $2.56 \%$, while for victims in accidents in general $2.27 \%$ - which indicates low variability (adopted interpretation of the coefficient of variation). The highest number of incidents in the analysed period of 2013-2017 were other (light) accidents, the effects of which do not cause long-term occupational absence - on average in the analysed period, 1071 injured were registered, in this type of incidents. The number of people injured in other accidents was characterized by low volatility (2.2\%), in 2016 a downward trend was recorded (1033 injured) in 2013-2015. In 2017, the trend was growing - an increase of $4.5 \%$ in relation to 2016 . Therefore, it is stated that the number of injured in other accidents oscillates at a similar level. Fig. 1 presents the number of accidents classified according to the severity of the consequences and the number of accident victims in the years 2013-2017.

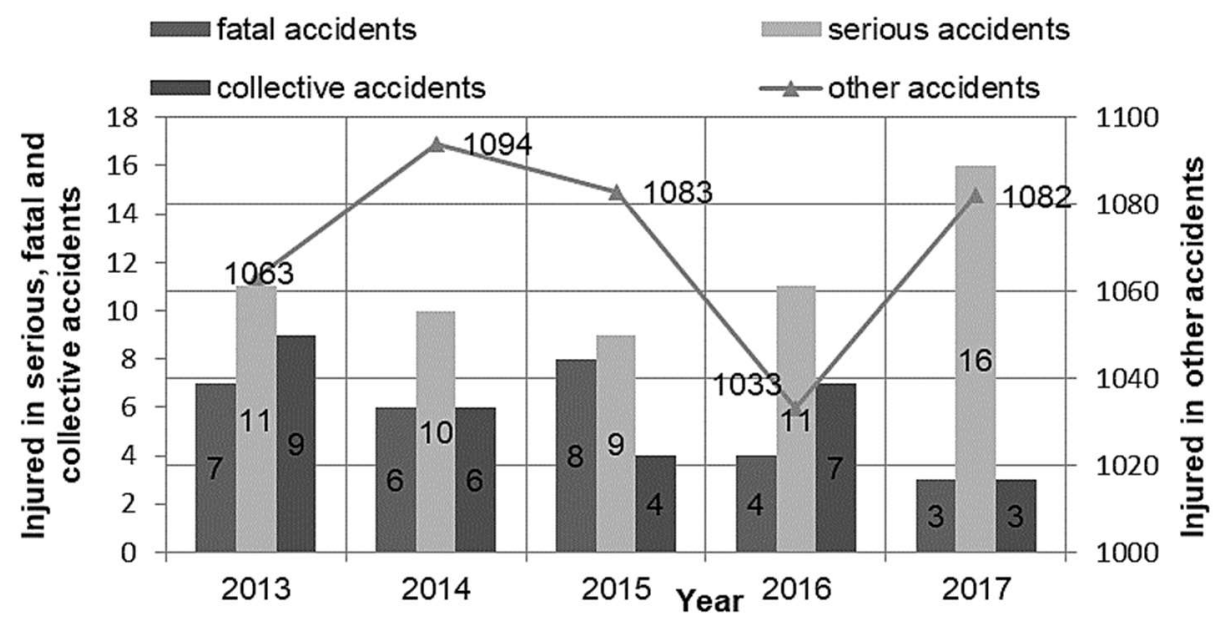

Fig. 1 The number of serious, fatal, collective and other accidents in 2013-2017

The number of people injured in fatal accidents is close to $<3.8>$. The value of the coefficient of variation is $37.0 \%$, moderate volatility - decrease in 2014 , increase in 2015 (8 victims in fatal accidents) and then decrease in 2016 and 2017. The number of injured persons was 4 and 3 persons respectively. An important element from the point of view of occupational safety would be to keep the trend decreasing for future years.

In case of the number of people injured in serious accidents, a small variability was recorded (the coefficient of variation was $23.7 \%$ ). The largest number of injured people was in 2017 (16 people), while the smallest number of people injured in 2015 (9 people injured). The tendency of this type of events in 20132015 was decreasing, while since 2016 their increase has been visible. Table 2 presents selected characteristics of descriptive statistics for the number of people injured in fatal, heavy, collective and other accidents. 
Table 2 Selected characteristics of descriptive statistics for accidents at work

\begin{tabular}{|l|c|c|c|c|c|c|}
\hline \multicolumn{1}{|c|}{ Specification } & Median & Min & Max & Deviation standard & Average & $\begin{array}{c}\text { Coefficient } \\
\text { of variation, \% }\end{array}$ \\
\hline Fatal accidents & 6 & 3 & 8 & 2.1 & 5.6 & 37.0 \\
\hline $\begin{array}{l}\text { Serious } \\
\text { accidents }\end{array}$ & 11 & 9 & 16 & 2.7 & 11.4 & 23.7 \\
\hline $\begin{array}{l}\text { Collective } \\
\text { accidents }\end{array}$ & 6 & 3 & 9 & 2.4 & 5.8 & 41.2 \\
\hline $\begin{array}{l}\text { Other } \\
\text { accidents }\end{array}$ & 1082 & 1033 & 1094 & 23.9 & 1071 & 2.2 \\
\hline
\end{tabular}

Source: own elaboration

The number of people injured in collective accidents closes in the both-sidebounded interval $\langle 3.9\rangle$. The value of the coefficient of variation was 41.2 , which indicates moderate volatility. In 2013, 9 people suffered from collective accidents, the tendency in 2014-2015 was decreasing (respectively 6 and 4 injured), then in 2016 an increase in the number of incidents (7 injured) was registered and in 2017 a decrease (3 victims) - a falling tendency.

The accidental events occurring in the use, repair and maintenance of machines translate into the number of days of employees' occupational absence. The highest number of days of incapacity to work was registered in 2016. At that time, the number of days of the incapacity amounted to 55746. The number of days of incapacity for work is characterized by low variability $(7.3 \%)$. In 20132016 there was an alternate growth and decrease, which may indicate a lack of tendency. However, in 2017 a downward trend was recorded. Fig. 2 shows the number of days of incapacity to work in the analysed period, while in Table 3 selected characteristics of descriptive statistics.

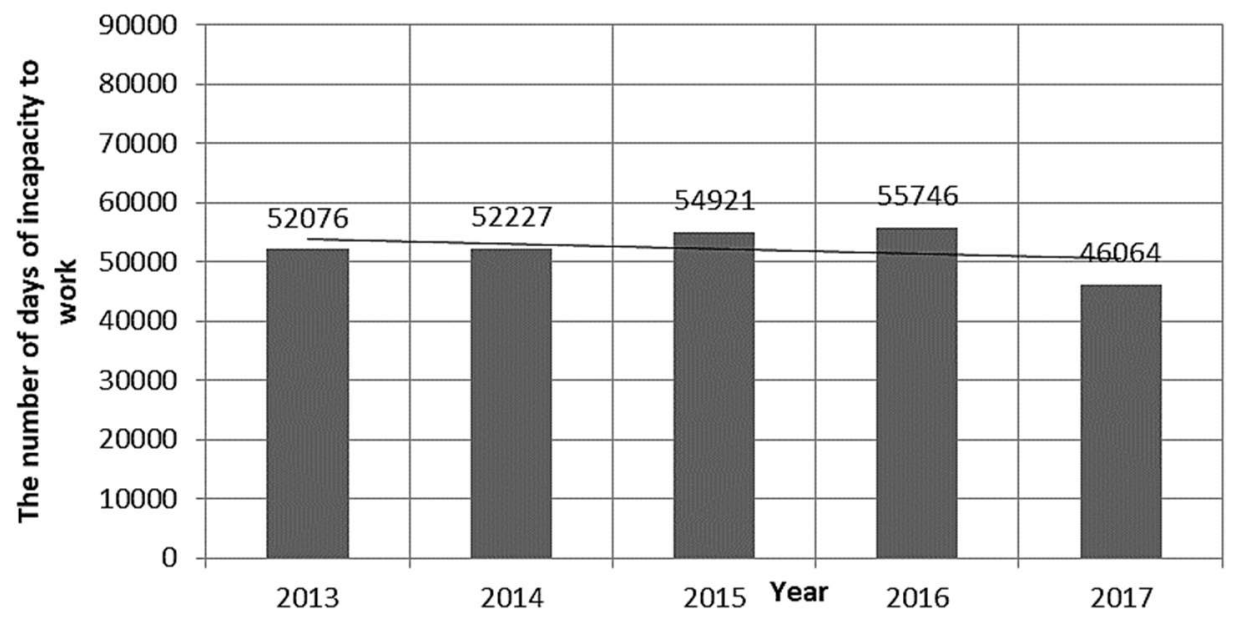

Fig. 2 The number of days in incapacity for work of people injured in accidents in the usage of repair and maintenance of machines

Table 3 Selected characteristics of descriptive statistics for the number of days incapacity to work

\begin{tabular}{|c|c|c|c|c|c|c|}
\hline Specification & Median & Min & Max & $\begin{array}{c}\text { Deviation } \\
\text { standard }\end{array}$ & Average & $\begin{array}{c}\text { Coefficient } \\
\text { of variation, \% }\end{array}$ \\
\hline $\begin{array}{c}\text { The number of days } \\
\text { of incapacity to work }\end{array}$ & 52227 & 46064 & 55746 & 3796.2 & 52206.8 & 7.3 \\
\hline
\end{tabular}




\section{RATIO ANALYSIS OF ACCIDENTS AT WORK}

In order to analyse the accident rate and the comparative analysis of the accident rate, basic frequency $\left(W_{z}, W_{z c}, W_{z s}\right)$ and accident severity $\left(C_{w}\right)$. The analysis of changes in the value of indicators covered the period of 6 years (2013-2017) - Table 4.

Table 4 Accident measurements

\begin{tabular}{|l|c|c|c|c|c|}
\hline \multicolumn{1}{|c|}{ Accident measurements } & $\mathbf{2 0 1 3}$ & $\mathbf{2 0 1 4}$ & $\mathbf{2 0 1 5}$ & $\mathbf{2 0 1 6}$ & $\mathbf{2 0 1 7}$ \\
\hline Total accident rate indicator $\left(\mathrm{W}_{\mathrm{z}}\right)$ & 11.76 & 11.82 & 11.55 & 10.51 & 10.96 \\
\hline Frequency rate indicator of severity accidents $\left(\mathrm{W}_{\mathrm{zc}}\right)$ & 11.97 & 10.65 & 9.45 & 11.03 & 15.92 \\
\hline Frequency rate indicator of fatal accidents $\left(\mathrm{W}_{\mathrm{zs}}\right)$ & 7.62 & 6.39 & 8.40 & 4.01 & 2.99 \\
\hline Accident severity rate $\left(\mathrm{C}_{\mathrm{w}}\right)$ & 48.49 & 47.31 & 50.29 & 53.40 & 41.95 \\
\hline
\end{tabular}

Source: Own elaboration

In order to compare the variation of the accident rate, selected characteristics of descriptive statistics were determined for the determined indicators. The interpretation of the coefficient of variation was also used for the purpose of the study. Selected descriptive statistics for accident indicators in the use, repair and maintenance of machines are summarized in Table 5.

Table 5 Selected characteristics of descriptive statistics for accident rates

\begin{tabular}{|l|c|c|c|c|c|}
\hline \multicolumn{1}{|c|}{ Accident measurements } & Min & Max & $\begin{array}{c}\text { Deviation } \\
\text { standard }\end{array}$ & Average & $\begin{array}{c}\text { Coefficient } \\
\text { of variation, } \%\end{array}$ \\
\hline $\begin{array}{l}\text { Total accident rate indicator } \\
\left(\mathrm{W}_{\mathrm{z}}\right)\end{array}$ & 10.51 & 11.82 & 11.32 & 0.57 & 5.0 \\
\hline $\begin{array}{l}\text { Frequency rate indicator } \\
\text { of severity accidents }\left(\mathrm{W}_{\mathrm{zc}}\right)\end{array}$ & 9.45 & 15.92 & 11.81 & 2.47 & 20.9 \\
\hline $\begin{array}{l}\text { Frequency rate indicator } \\
\text { of fatal accidents }\left(\mathrm{W}_{\mathrm{zs}}\right)\end{array}$ & 2.99 & 8.40 & 5.88 & 2.32 & 39.4 \\
\hline Accident severity rate $\left(\mathrm{C}_{\mathrm{w}}\right)$ & 41.95 & 53.40 & 84.29 & 4.22 & 8.7 \\
\hline
\end{tabular}

Source: Own elaboration

The values of the total accident rate index $\left(\mathrm{W}_{\mathrm{z}}\right)$ on the number of people on average employed in the use, repair and maintenance of machines is characterized by low volatility (5.0\%), upward trend in $2014\left(\mathrm{~W}_{z}=11.82\right)$, ), in 2015, 2016 declining $\left(W_{z}=11.55 ; W_{z}=10.51\right)$ and in 2017 there was an increase by $4.1 \%$ in relation to $2016-W_{z}=10.96$.

The values of the frequency indicator of serious accidents are characterized by low variability $(20.9 \%)$ - according to the accepted interpretation of the coefficient of variation. A downward trend was recorded in 2014, $2015\left(\mathrm{~W}_{\mathrm{zc}}=\right.$ 10.65; $\left.W_{\mathrm{zc}}=9.45\right)$ compared to 2013 and an upward trend in 2016 and 2017 $\left(W_{z c}=11.03 ; W_{z c}=15.92\right)$.

On the basis of the analysis of the value of the frequency indicator of fatal accidents, its moderate variability is found $-39.4 \%$. In $2013-2015$, its increase and decrease is observed, while in 2016, 2017 a downward trend is visible - the values of the indicator were respectively: $W_{z s}=4.01$ and $W_{z s}=2.99$.

The value of the severity index of accidents determined as the quotient of the number of days of occupational absence to the number of people injured in total accidents, reduced by the number of people injured in fatal accidents, ranges from 41.95 to 53.40 . It is characterized by low volatility $-8.7 \%$ - a decrease in 
2014 (compared to 2013), an increase in 2015-2016 and a decrease in 2017. Its maximum value was 53.40 and was registered in 2016.

\section{CASUSES OF ACCIDENTS WHEN USING, REPAIRING AND MAINTAINING MACHINES}

Ensuring work safety in the use, repair and maintenance of machines is possible by implementing practices to eliminate the causes of accidents at work. In connection with the above, the activities in which negative events occurred in 2013-2017 have been identified. Based on the analysis, it is stated that the activities in which most accidents at work occurred in the analysed period of 2013-2017 were:

- movement of an employee (including walking, running, going up and down) Fig. 3. This operation, on average, for the examined time period was the source of $29 \%$ of accidents - Fig. 4 .

- work with hand tools (non mechanised and mechanised). On average, for the analysed time period, it was the source of $23.2 \%$ of unwanted events;

- handling objects - including handholds, grasping, this activity was on average the source of $19 \%$ of events.

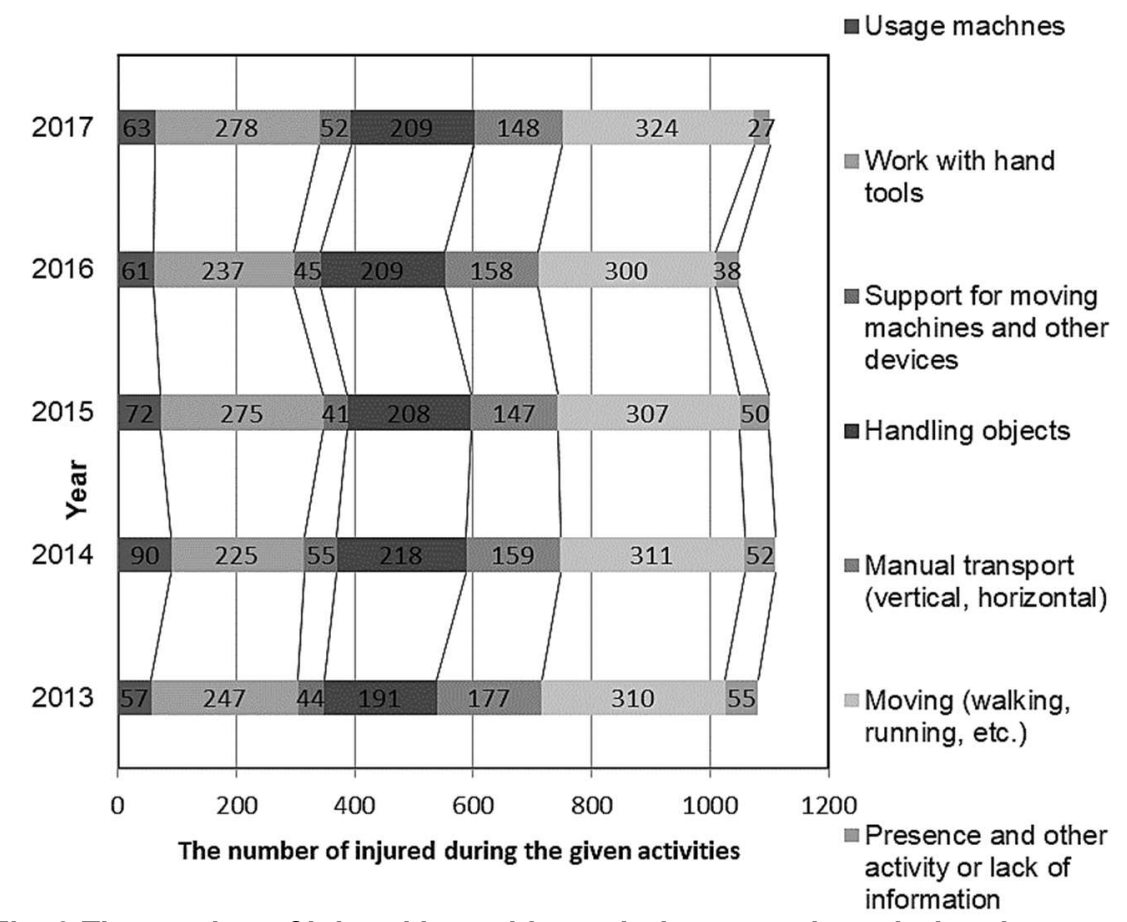

Fig. 3 The number of injured in accidents during operations during the usage, repair and maintenance of machines

On the other hand, activities in which incidents were the least frequent were related to: lack of information $(4.1 \%)$, operating mobile machines and other devices (operating machines and other mobile devices with their own drive) $4.4 \%$ and daily servicing - i.e. starting, stopping $-6.3 \%$. 


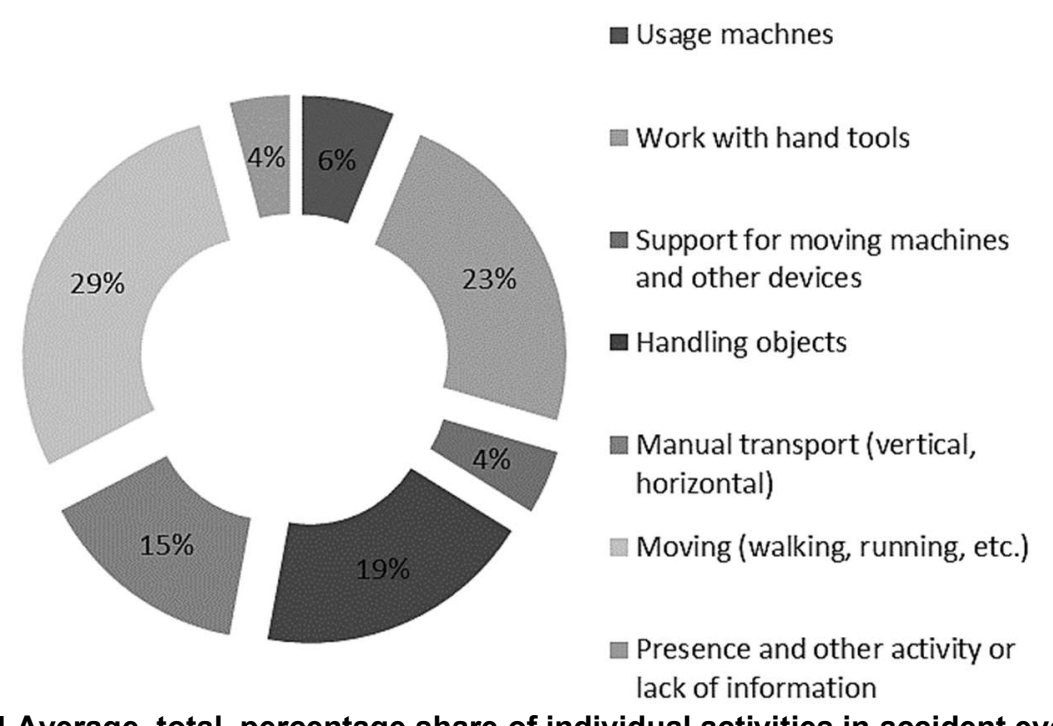

Fig. 4 Average, total, percentage share of individual activities in accident events

\section{CONCLUSION}

Designing safe and hygienic working conditions in the use, repair and maintenance of machines is possible by implementing technical and organizational solutions in industrial enterprises. But also any technological process can be harmful to the health of the employee (Skuza et. al., 2011). In the analysed area, the most frequent accidents that occur are so called light, not causing serious health effects, or long-term occupational absence. For these events, as compared to 2017 , no declining trend is observed, which may be a reason for their upward tendency.

Heavy, fatal and collective accidents are also recorded for the area related to the use, repair and maintenance of the machine. Occurrence of such events translates into an increase in social and economic costs incurred by enterprises. Heavy accidents in the years 2016-2017 were characterized by an upward trend, while in case of collective, fatal ones the tendency was decreasing.

In order to determine during which activities accidents occur while using, repairing and maintaining of machines, their identification was carried out. The conducted analysis allowed to conclude that areas that require improvement, raise of employees awareness in aspects related to the movement of employees (communication routes, their layout, etc.), work with tools carried out, or operation of objects. Prophylactic solutions that have an impact on the improvement of safety in this area may be, equipping workers with appropriate protective means depending on the surface on which employees move, equipping them with easily accessible work instructions.

The analysis of statistical data also allows us to state that the machinery park, which is used, to a large extent meets the legal requirements discussed in the study. However, there are enterprises in which the problem of meeting the minimum and essential requirements still exists. In these enterprises, the servicing of machines is a source of accidents at work $-6.3 \%$ in total for the entire analysed time period, or operation of mobile machines $-4.4 \%$. Thus, it can be stated that the operation of machines is a total of approx. $10.7 \%$, which, 
however, requires further tilting over the issues of occupational safety in the operation of machines. The solution to this problem may be more frequent machine safety audits, carried out in accordance with the existing working conditions, the company's technological profile.

\section{REFERENCES}

Act of June 26, 1974. The Labour Code. Available at:http://prawo.sejm.gov.pl/isap.nsf/download.xsp/WDU19740240141/U/D197401 41 Lj.pdf [Accessed 1 June 2019].

Act of October 30, 2002 on social insurance for accidents at work and occupational diseases.

Directive 2009/104/EC of the European Parliament of the Council of 16 September 2009 concerning the minimum safety and health requirements for the use of work equipment by workers at work.

Directive 2006/42/EC of the European Parliament and of Council of 17 May 2006 on machinery.

Furman, J., Kuczyńska-Chałada, M., Poloczek R. (2018). Improvement of production processes with the use of Lean Manufacturing tools. MAPE 2018, [online] Volume 1(1), pp. 529-535. Available at: https://content.sciendo.com/abstract/journals/mape/1/1/article-p529.xml [Accessed 1 June 2019].

Furman, J., Kuczyńska-Chałada, M., Pawlak, S. (2017). The influence of lean manufacturing tools on the product quality in the casting process - case study. In: METAL 2017: $26^{\text {th }}$ International Conference on Metallurgy and Materials, Ostrava: Tanger, p. 2220.

Gajdzik, B., Wyciślik, A. (2016). Ramowe zasady implementacji metody 5 S w laboratorium chemicznym. Przemysł Chemiczny, vol. 2, issue: 1, pp.10-13.

Gajdzik, B. (2013). World Class Manufacturing in metallurgical enterprises Metalurgija, vol. $52, \quad$ issue: $1, \quad$ pp. 131-134. Available at:https://hrcak.srce.hr/index.php?show=clanak\&id_clanak_jezik=129153

Gala, B., Wolniak, R. (2013). Problems of implementation 5S practices in an industrial company. Management System in Production Engineering, vol. 12, no. 4, pp. 8-14. Available at:http://wydawnictwo.panova.pl/pliki/12_2013/2013_12_02_Gala.pdf

Kuczyńska-Chałada, M., Furman, J., Pawlak, Sz. (2017). The implementation of 5S method in the production plant which conducts casting operations. In: METAL 2017: $26^{\text {th }}$ International Conference on Metallurgy and Materials, Ostrava: Tanger, p. $2219-2222$.

https://stat.gov.pl/obszary-tematyczne/rynek-pracy/warunki-pracy-wypadki-przy-pracy/ [Accessed 1 June 2019].

Lis, T., Nowacki, K (2005). Occupational health and safety management in an industrial plant. Publishing Silesian University of Technology.

Lis, T., Nowacki, K., Kania, H., Jucha, S. (2016). System LOCKOUT - TAGOUT dla bezpieczeństwa pracy. In R. Knosala, ed., Innowacje w zarządzaniu i inżynierii produkcji, Opole: Oficyna Wydawnicza PTZP, pp. 413-421. Available at:http://www.ptzp.org.pl/files/konferencje/kzz/artyk_pdf_2016/T2/t2_0413.pdf

Regulation of the Minister of Economy of October 30, 2002 on minimum requirements regarding health and safety at work in the use of machines by employees at work.

Małysa, T, Nowacki, K., Lis, T. (2017). The correlation between structure of employment and accidents at work in metallurgical enterprises. In: METAL 2017: $26^{\text {th }}$ International Conference on Metallurgy and Materials, pp. 2244-2249.

Małysa, T., Nowacki, K., Furman, J. (2016). The risk management methodology in the metallurgical enterprises. In: METAL 2016: $25^{\text {th }}$ International Conference on Metallurgy and Materials, pp. 1925-1930. 
Małysa, T., Pawlak, Sz. (2017). Selection of preventive solutions as an element of improving safety of work with usage of machines, Scientific Papers of Silesian University of Technology. Organization and Management Series, pp. 267-278. Available https://www.polsl.pl/Wydzialy/ROZ/ZN/Documents/z\%20105/20\%20Ma\%C5\%82y sa, \%20Pawlak.pdf [Accessed 1 June 2019].

Moeuf, A. Tamayo, S., Lamouri, S., Pellerin, Lelievre, A. (2016). Strengths and weaknesses of small and medium sized enterprises regarding the implementation of lean manufacturing. IFAC-Paper On Line, vol.49, issue: 12, pp. 71-76. Available at: https://www.sciencedirect.com/science/article/pii/S2405896316308059.

Skuza, Z., Prusak, R., Budzik, R. (2011) Contemporary elements of quality management system in the metallurgical enterprises. Metalurgija, vol. 50, issue: 2 , pp. 137-140.

Wolniak, R. (2013). Metody i narzędzia lean production i ich rola w kształtowaniu innowacji w przemyśle. In R. Knosala, ed., Innowacje w zarządzaniu i inżynierii produkcji, Opole: Oficyna Wydawnicza PTZP, pp. 524-533. Available at:http://www.ptzp.org.pl/files/konferencje/kzz/artyk_pdf_2013/p049.pdf

\begin{abstract}
.
The usage, repair and maintenance of machines is one of the areas in which it still records a significant number of accident events. The occurrence of accidents at work generates social and economic costs for the enterprise. Therefore, employers should be take measures to improve safety at the workplace. The publication presents an accident analysis based on a comparison of the following measures: accident rates (i.e. number of accidents, event effects) and ratio analysis (frequency rate indicator and total accident rate indicator). Calculated indicators allowed to determine the accident rate during the usage, repair and maintenance of machines. The analysis covered a five-year period - i.e. 2013-2017. On the basis of the analyzes carried out, the proposal was presented of possible prevention solutions to reduce the number of accidents at work.
\end{abstract}

Keywords: accident rate, safety at work, usage, repair and maintenance of machines 